\title{
Customer Contentment in E-retailing of Millennial Generation in Chennai City
}

\author{
T. S. Bhuvaneswari, A. Anis Akthar Sulthana Banu
}

\begin{abstract}
E- Retailing is a commercial transaction wherein exchange of goods and services are taking place through the internet with the assistance of electronic gadgets such as Mobile phones, Tablets, Laptops, Desk top Computers, Automated vending machines, Kiosk Machines, etc. The advancement of digital technology has transformed the "Baby Boomers" to "Digital Natives" who are well acquainted with the electronic widgets/doodads to get ready themselves for e-Retailing transactions. E- retailing is a modern commercial platform that provides enormous variety of commodities with varied offers, discounts and features blended with flexible payment modes. A Customer is said to be well contented when they realize their expectations are almost fulfilled right from ordering the products till they ultimately consumed leading to Customer Satisfaction. This research paper makes an attempt to understand the behavioral pattern of the millennia's and the challenges it creates for Online retail organizations. A principal data is generated by serving a structured questionnaire to a random sample of 100 online buyers in Chennai City to identify their buying behaviour for describing the level of satisfaction of E- retailing business. With the help of Statistical analysis using the tools such as ANOVA, Chi-Square and Factor study it has been revealed that millennials are tapping the recent technological improvements in e-retailing business to augment their fulfilment and well influenced by the Socio-Economic variables for maximizing the Overall Satisfaction.
\end{abstract}

Keywords : E- tailing, Millennial, Tech-Savvy, Customer Delight.

\section{INTRODUCTION}

Satisfaction is an individual's emotional state of delight or failure of expectation consequential to contrasting a products' perceived. Customer satisfaction is acknowledged as the driving force in the development of prospective consumers with an intention to acquire tha product. Satisfied customers are valued as the resources of any business concern in the current cut-throat epoch since they will possibly to inform others about their gainful exposure and hence engage in effective "word of mouth" promotion.

E-retailing the exchange of retail merchandise and services through online or Inter connected network.. It

employs the "Business to Customer" Trade model wherein

Revised Manuscript Received on December 05, 2019.

* Correspondence Author

Dr. T. S. Bhuvaneswari*, Assistant Professor, Department of Accounting $\&$ Finance, Patrician College of Arts and Science, Chennai, India. Email id: bhuvaneswari.acc@gmail.com

Dr. A. Anis Akthar Sulthana Banu, Assistant Professor, Department of B. Com (CS) \& Information Systems Management, Justice Basheer Ahmed Sayeed College for Women, (Autonomous)(AN), Chennai, India. Email id:anisakthar1974@gmail.com the company interfaces directly with the clients without the intervention of any intermediaries. The e - retailers are categorized in to pure play e- retailers and brick and click eretailers. Amazon, is known as pure play e- retailers where the goods are sold through network and having no corporal store for the clientele. In brick and click e- retailers sell the products through the internet as well as having the physical shop for the customers. similar to common marketing actions of an organization, e-retailers also embedded in the marketing mix (4P's of marketing). E-store offer an immense variety of merchandise offerings like conventional merchants in categories assorted from electronics to household products which dispense every type of product and render services to the e-customers at the tick of a mouse cursor and generates income by selling products straight to the e-customers Flipkart, Amazon, Snapdeal, Book My show, Myntra etc. are few leading E- Retailers.

\section{A. Satisfaction of Millennials in E-retailing}

The millennials are called as the "digital Whiz", the "instantaneous messaging generations", the "trophy kids" Generation Y. They are most highly educated and are technologically knowledgeable, sophisticated, and ironically motives by self - interest, over involved, highly encouraging.

Customer Satisfaction is a positive outcome of the circumstances in which commodities and services that are purchased by a customer, meet the hope so it becomes satisfied with them that provided by the e-retailing. The preceding factors influence customer satisfaction in e-retailing are website Architecture, protection, data excellence, disbursement mode, e-service standards, merchandise value, diversification of goods and delivery services. The key to retail success really lines in keeping millennials happy. The online fashion purchases are dominated by younger shoppers. Every sector has a significant and growing audience of millennial buyers with a set of behaviours, wants and expectations that are very different to other demographics. If brands want to capture the attention and long-term of the younger shopper, the way to foster and maintain loyalty needs to change. This paper delineates about the satisfaction of millennials and to identify the buying behaviour of goods or services through e-retailing.

Published By:

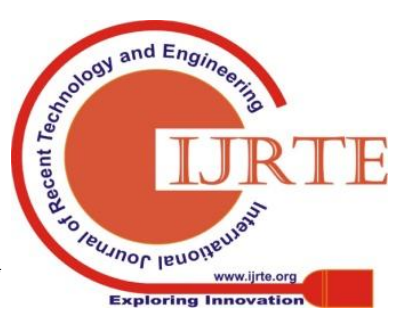




\section{REVIEW OF LITERATUR}

Rajeswari.M (2015) found that the respondents are more internet know-how day by day. As they become self-assured and are prepared to purchase costly products through Internet and suggested that the Electronic market has to lessen the consumer perceived risks by developing shopping gateway easier to navigate, provide protected disbursement option, speed delivery and maintain trust and feel the experience of missing touch.

Feroj Mahmood (2016) revealed that that Electronic Commerce has revolutionized our country by altering the approach businesses used to be. Everyday novel technology is introduced and it captures the customers mind rapidly. Electronic business is the prospect of shopping and service. With the expansion of internet communication technology users of internet are going enormous way.

Weideman. A(2014) recommended that smartphone manufactures must afford consumers with a client service, appliance to evaluate customer's contentment in terms of their requirements and also pioneer the innovative ways to correspond with Millennial consumers to create brand loyalty.

\section{OBJECTIVES OF THE STUDY}

- To learn the economic and societal factors of millennials satisfaction towards e-retailing.

- To identify the buying behaviour towards e retailing products or services.

- To find the major challenges for e - retailers in present scenario.

\section{A. Hypothesis}

- The socio-economic parameters of Online Consumers are not driving them for contentment in E- Retailing transactions.

- The Buying behaviour attributes are not coupled with the contentment level of consumers.

\section{RESEARCH METHODOLOGY}

In this study descriptive research design is adopted to identity and describe the satisfaction of millennials towards e-retailing in Chennai City. The study depends upon Principal data that is collected through survey method using well structured questionnaire. Random sampling method is followed for data collection. Totally 100 questionnaires were circulated and collected from the generation Y customers who are online users. The data were analysed by using SPSS 23. ANOVA, Chi - square and Exploratory Factor Analysis (EFA) with principle components analysis (PCA) was used to examine the validity.

\section{DATA ANALYSIS AND INTERPRETATION}

To understand the socio-economic characters of millennials satisfaction towards e-retailing.

Null Hypothesis (H0): There is no significant influence of socio-economicvariables on the Customer contentment towards E-retailing.

Alternate Hypothesis (H1): There is a strong influence of socio-economicvariables on the customer contentment towards $E$ - retailing

Table - 1:One Way ANOVA

\begin{tabular}{|c|c|c|c|c|c|c|}
\hline Socio Economic Factors & & Sum of Squares & Df & Mean Square & $\mathbf{F}$ & Sig. \\
\hline \multirow{3}{*}{ Age } & Between Groups & 16.706 & 8 & 2.088 & 2.937 & .006 \\
\hline & Within Groups & 63.981 & 90 & .711 & & \\
\hline & Total & 80.687 & 98 & & & \\
\hline \multirow{3}{*}{ Occupation } & Between Groups & 51.100 & 8 & 6.387 & 11.223 & .000 \\
\hline & Within Groups & 51.224 & 90 & .569 & & \\
\hline & Total & 102.323 & 98 & & & \\
\hline \multirow{3}{*}{ Gender } & Between Groups & 5.295 & 8 & .662 & 3.111 & .004 \\
\hline & Within Groups & 19.149 & 90 & .213 & & \\
\hline & Total & 24.444 & 98 & & & \\
\hline \multirow{2}{*}{ Qualification } & Between Groups & 21.223 & 8 & 2.653 & 3.928 & .001 \\
\hline & Total & 82.000 & 98 & & & \\
\hline \multirow{3}{*}{ Income } & Between Groups & 60.436 & 8 & 7.555 & 5.071 & .000 \\
\hline & Within Groups & 134.069 & 90 & 1.490 & & \\
\hline & Total & 194.505 & 98 & & & \\
\hline \multirow{3}{*}{ Marital Status } & Between Groups & 3.103 & 8 & .388 & 2.398 & .022 \\
\hline & Within Groups & 14.554 & 90 & .162 & & \\
\hline & Total & 17.657 & 98 & & & \\
\hline Family Type & Between Groups & 31.216 & 8 & 3.902 & 5.052 & .000 \\
\hline
\end{tabular}




\begin{tabular}{|l|c|c|c|c|c|}
\hline & Within Groups & 69.512 & 90 & .772 & \\
\cline { 2 - 6 } & Total & 100.727 & 98 & & \\
\hline
\end{tabular}

Source: Primary Data

Interpretation: As the $\mathrm{P}$ value for all the socio-economic variables are less than 0.05, the Null Hypothesis is discarded and Alternate Hypothesis is accepted. Hence the above societal and economic attributes such as Age, Occupation, Gender, Income, Academic Qualifications, Marital Status and Type of the Family significantly persuade the E-retailing customers for Overall Satisfaction.

To identify the buying behaviour towards E-retailing products or services

Null Hypothesis (H0): The Buying behaviour attributes are not coupled with the contentment level of consumers Alternate Hypothesis (H1): There is a Strong relationship among Customer buying behaviour and contentment level.

Table - 3: Chi-Square Test - Frequencies - Periodicity of Purchase

\begin{tabular}{|c|c|c|c|}
\hline Periodicity of Purchase & Observed N & Expected N & Residual \\
\hline Once a week & 16 & 16.5 & -.5 \\
\hline At least once in a month & 25 & 16.5 & 8.5 \\
\hline Once in 2-4 months & 17 & 16.5 & .5 \\
\hline Once in a year & 8 & 16.5 & -8.5 \\
\hline According to the need & 24 & 16.5 & 7.5 \\
\hline Never & 10 & 16.5 & -7.5 \\
\hline Total & 100 & & \\
\hline
\end{tabular}

\begin{tabular}{|c|c|c|c|}
\hline Online Advertisements & 3 & 16.5 & -14.5 \\
\hline Total & 100 & & \\
\hline
\end{tabular}

Table - 5: Mode of Payment

\begin{tabular}{|c|c|c|c|}
\hline Mode of Payment & Observed N & Expected N & Residual \\
\hline Credit card & 4 & 14.1 & -10.1 \\
\hline Debit card & 27 & 14.1 & 12.9 \\
\hline Demand draft & 2 & 14.1 & -12.1 \\
\hline Net banking & 8 & 14.1 & -6.1 \\
\hline Cash on Delivery & 51 & 14.1 & 36.9 \\
\hline Others & 7 & 14.1 & -9.1 \\
\hline Total & 100 & & \\
\hline
\end{tabular}

Table - 6: Test Statistics

\begin{tabular}{|c|c|c|c|}
\hline & $\begin{array}{c}\text { Periodicity of } \\
\text { Purchase }\end{array}$ & $\begin{array}{c}\text { Sources of } \\
\text { Information }\end{array}$ & $\begin{array}{c}\text { Mode or } \\
\text { Payment }\end{array}$ \\
\hline Chi-square & $15.606^{\mathrm{a}}$ & $227.848^{\mathrm{a}}$ & $144.444^{\mathrm{b}}$ \\
\hline Df & 5 & 5 & 6 \\
\hline Asymp. Sig. & .008 & .000 & .000 \\
\hline
\end{tabular}

Interpretation: The above Chi Square analysis revealed the fact that there exists a positive relationship between the buying behaviour attributes and the level of contentment of customers as the $\mathrm{p}$ value of the table is less than 0.05 .

Table - 4:Sources of Information

\begin{tabular}{|c|c|c|c|}
\hline Sources of Information & $\begin{array}{c}\text { Observed } \\
\mathbf{N}\end{array}$ & Expected N & Residual \\
\hline Google, Yahoo & 72 & 16.5 & 55.5 \\
\hline Product Catalogues & 2 & 16.5 & -14.5 \\
\hline Friends \& Family & 8 & 16.5 & -8.5 \\
\hline Blogs & 11 & 16.5 & -5.5 \\
\hline Product reviews in the print media & 4 & 16.5 & -12.5 \\
\hline
\end{tabular}

To study the major challenges for e-retailers in present scenario

Table - 7: Factor Analysis - KMO and Bartlett's Test

\begin{tabular}{|c|c|c|}
\hline \multicolumn{2}{|c|}{ Kaiser-Meyer-Olkin Measure of Sampling Adequacy. } & .459 \\
\hline \multirow{3}{*}{ Bartlett's Test of Sphericity } & Approx. Chi-Square & 63.286 \\
\cline { 2 - 3 } & Df & 21 \\
\cline { 2 - 3 } & Sig. & .000 \\
\hline
\end{tabular}

Table - 8: Factor Analysis - Total Variance Explained

\begin{tabular}{|c|c|c|c|c|}
\hline \multirow{2}{*}{ Component } & \multicolumn{4}{|c|}{ Initial Eigenvalues } \\
\hline & Total & \multicolumn{2}{|c|}{$\%$ of Variance } & $\underset{\%}{\text { Cumulative }}$ \\
\hline Speed of the internet & 1.681 & \multicolumn{2}{|c|}{24.018} & 24.018 \\
\hline Cash on delivery & 1.326 & \multicolumn{2}{|c|}{18.945} & 42.963 \\
\hline Payment gateways & 1.248 & \multicolumn{2}{|c|}{17.832} & 60.795 \\
\hline Discounted price & .991 & \multicolumn{2}{|c|}{14.160} & 74.955 \\
\hline On time delivery & .747 & \multicolumn{2}{|c|}{10.672} & 85.627 \\
\hline Moneyback refund & .567 & \multicolumn{2}{|c|}{8.102} & 93.728 \\
\hline Expertise of merchant & .439 & \multicolumn{2}{|c|}{6.272} & 100.000 \\
\hline \multicolumn{5}{|r|}{ Source: } \\
\hline \multicolumn{5}{|c|}{ Table - 9: Factor Analysis - Rotated Component Matrix } \\
\hline & & \multicolumn{3}{|c|}{ Component } \\
\hline & & 1 & 2 & 3 \\
\hline Speed of the internet & & & .673 & \\
\hline Cash on delivery & & & & .379 \\
\hline Payment gateways & & .723 & & \\
\hline Discounted price & & .840 & & \\
\hline On time delivery & & & & .565 \\
\hline
\end{tabular}

\begin{tabular}{|c|c|c|c|c|c|}
\multicolumn{3}{|c|}{$\begin{array}{c}\text { Extraction Sums of Squared } \\
\text { Loadings }\end{array}$} & \multicolumn{3}{c|}{ Rotation Sums of Squared Loadings } \\
\hline Total & $\begin{array}{c}\text { \% of } \\
\text { Variance }\end{array}$ & $\begin{array}{c}\text { Cumulative } \\
\text { \% }\end{array}$ & Total & $\begin{array}{c}\text { \% of } \\
\text { Variance }\end{array}$ & Cumulative \% \\
\hline 1.681 & 24.018 & 24.018 & 1.509 & 21.562 & 21.562 \\
\hline 1.326 & 18.945 & 42.963 & 1.387 & 19.807 & 41.369 \\
\hline 1.248 & 17.832 & 60.795 & 1.360 & 19.425 & 60.795 \\
\hline & & & & & \\
\hline & & & & & \\
\hline
\end{tabular}

Interpretation: Using Principal Component Analysis, the following prominent factors are identified for meeting the challenges of e- retailers. They are as follows.

FACTOR 1: PRICE RELATED Challenges such as Offers and Discounts, Payment Gateways, ete- that contributes to $21.56 \%$ of the total variance. 
FACTOR 2: EFFICIENCY RELATED challenges such as Speed of the Internet and the expertise of the Merchants are contributing $19.80 \%$ of the total variance explained.

FACTOR 3: LOGISTICS RELATED Challenges such as On Time Delivery, Product Returns and Money Back Refunds, etc. that carries $17.83 \%$ of the total variance.

\section{FINDINGS}

Societal and economic factors such as Age, Occupation, sex, Monthly Income, Academic Qualifications, Marital Status and Type of the Family significantly persuade the E-retailing customers for Overall Satisfaction.

Chi Square analysis revealed the fact that an optimistic affiliation is found amid the buying conduct attributes and the level of contentment of millennial clients.

The customers satisfaction is roped with offers, discount, payment mode, speed of the internet, delivery and money back refunds.

\section{CONCLUSION AND SUGGESTION}

From the data analysis it is concluded that the millennials customers are satisfied when they come across all the attributes of product. The millennials explore more information from Google, and they purchase the products at discount price and offers, and prefer to make payment through payment gateways. Trading through electronic mode is intimately connected to the quality of services provided by the web-based shopping atmosphere. Triumphant E-retailing is attained by making the most of in-home shopping advantage, enabling e-shoppers feel comfy and certain to do an online procurement. Millennials are Tech - Savvy and they grew up with technology, and they rely on it to perform their purchases better.

\section{REFERENCES}

1. Feroj Mahmood S.M (2016), "E-Commerce, Online Shopping and Satisfaction: An Empirical Study on E-Commerce System in Dhaka", International Journal of Entrepreneurship and Development Studies (IJEDS) 4(3), 2016, 323-338.

2. Rajeswari. M (2015), "Astudy on the customer satisfaction towards online shopping in Chennai City", International Sales and Marketing Management Research and Development vol-5,Issue -1, pg 1 - 10, Feb 2015, ISSN(P) -2249-6939; ISSN(E) - 2249 - 8044.

3. Weideman. A (2014), Determining Generation Y's Customer Satisfaction, brand loyalty and relationship intention towards smart phone brands, Dissertation, University of Johannesburg.

4. www.google.com

5. www.sciencedirect.com

6. www.shodhganga.com

\section{AUTHORS PROFILE}

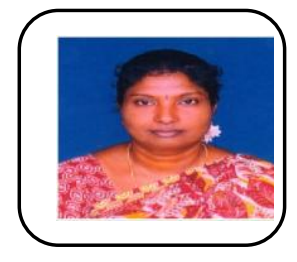

DR.T.S.Bhuvaneswari presently working as Assistant Professor in Department of Accounting and Finance at Patrician College of Arts and Science College, Adyar, Chennai. Has obtained M. Com and M.Phil. degree from University of Madras, Ph.D. from Bharathiar University, Coimbatore and has 12 years of experience in teaching to Under Graduate and Post Graduate students of BBA, Commerce and Accounting and Finance. Area of specialisation is Human Resource Management and Finance. And has published many articles in International Journals, attended and participated in National and International Seminars and Conferences.

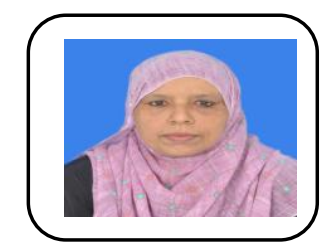

Dr. A. Anis Akthar Sulthana Banu, presently working as Associate Professor in Department of Corporate Secretaryship and Information Systems Management at Justice Basheer Ahmed College for Women (Autonomous)(AN),Teynampet. Has obtained M. Com and M.Phil. degree from University of Madras, Ph.D. from Manonmaniam Sudndaranar University, and Tirunelveli and qualified National Eligibility Test in Commerce and has 21 years of experience in teaching to Under Graduate and Post Graduate students of BBA, Commerce and Corporate Secretarship. Area of specialisation is Human Resource Management and Finance. And has published many articles in International Journals, attended and participated in National and International Seminars and Conferences. 